\title{
Gigging on the World Stage: Bossa Nova and Afrobeat after De-reification
}

\section{Naeem Inayatullah*}

\begin{abstract}
By focusing on the musical styles known as bossa nova and afrobeat, I ask: Given that globalisation/capitalism promotes exchange, borrowing, and imitation, can we make sense of 'authenticity'? Can we speak of an authentically Brazilian or Nigerian music? If today 'authenticity' makes little sense, why is talk about 'authenticity' so pervasive? If we expose 'authenticity' as reification, do we still need this term? What, then, may 'authenticity' mean? How can we restrict powerful musical cultures without limiting localities to replicating the past? How can cultures take up each others' vitality without losing their particularity? Can we imagine a world stage inviting all music? I explore the astonishing but mostly uncharted flows between and within musical traditions. At the same time, I seek to ground those flows in locales. Moving somewhat against the grain of contemporary social theory, I retrieve the need for 'reification' and 'authenticity'. If we value a diverse world, we may wish to balance capitalism's dominant flows with the desire to situate music-making in specific locales.
\end{abstract}

Key words: Bossa Nova; Afrobeat; Reification; Authenticity; De-Reification.

\section{Introduction}

'What is this element we call the authentic?' - Brennan (2008: 85) ${ }^{1}$

The place was packed. The stage was ready, with a DJ and three sound-checked microphones. The architecture of the lecture hall was benign; the 250 seats sloped down gently towards the stage where I had given many talks. Urged by a colleague, I was there to witness DAM, a Palestinian hip-hop group. As I waited, I delighted in the conversion of a lecture hall into a gigging venue, but didn't expect more. Because ...

Because I confess that hip-hop/rap baffles me. Its banal lyrics, obvious rhythms, and global reach trigger my preservationist impulses. Nevertheless, DAM's performance was captivating. Despite my body's rejection of their canned soundtrack, I could not resist their Arabic/Hebrew/English vocals and their kinesthetic charisma. They had me. Still, after the

* Ithaca College, Ithaca, NY, United States, naeem@ithaca.edu. 
show, I returned to my sense of loss. I re-imagined DAM performing with rhythms and forms closer to their probable roots, preferring what I imagined to what I had experienced. Slapping my wrist, I reprimanded myself for being a 'bad theorist'. How dare I deny them their selected form? Did I wish to ossify them for ethnomusicological posterity?

My paralysis was not altogether unproductive. It allowed me to squeeze out a few questions: How do we delimit powerful musical cultures (such as hip-hop) without at the same time reducing local music to exotica? How can all musical forms gain access to the world stage? Can cultures influence each other without losing themselves? What meaning does 'authenticity' carry when global flows, borrowing, and exchange saturate cultures? Can Nigerians or Brazilians, for example, claim any music as their own?

Consider the famed Nigerian musician Fela Kuti's influences. They include the funk of James Brown; the modal experimenting of Miles Davis and John Coltrane; the percussive depth of the Afro-Cubans Mario Bauza and Machito; and the vocal exuberance of Louis Prima. Or take João Gilberto who, with Antonio Carlos Jobim, Vinicius de Moraes and Carlos Lyra, created the Brazilian style known as bossa nova. Gilberto's influences include the vocal minimalism of Frank Sinatra, the west coast cool jazz of Stan Getz, and the neo-African percussion of northern Brazil.

Nor were the influences unidirectional. James Brown's bassist, Bootsy Collins, admits to Kuti's strong influence on James Brown's band (Veal 2000; Olorunyomi 2003: 10; Olaniyan 2004). Rock stars such Ginger Baker and Paul McCartney as well as the jazz trumpeter Lester Bowie flew to Lagos to play with Fela. Likewise, in the early 1960s many highly regarded jazz artists produced a bossa nova album. They include Ella Fitzgerald, Coleman Hawkins, Sarah Vaughn, Cannonball Adderley, Stan Getz and Charlie Byrd. Eventually, Frank Sinatra sought Antonio Carlos Jobim's collaboration, thus completing the circle of reciprocal influence.

If multiple sources influence styles, then surely claims to 'authenticity' remain incomprehensible. ${ }^{2}$ Nevertheless, do we still need 'authenticity' in our music? What may 'authenticity' mean once we have turned nouns into verbs (Mackey 1992), and de-reified things into processes?

Before Fela Kuti became famous, he gigged with his band in London, Lagos, and at various venues in the United States. Listening to Fela's band in that period, I remain unmoved. Their jazz/funk sound is difficult to place. Indeed, Fela produced his distinctive 'afrobeat' only after confronting the absent 'Nigerian' and 'African' roots in his sound (Collins 2009: 26, 135). After his 1969 United States tour, Fela addressed this problem by making a number of changes. He transposed traditional African drumming roles into parts for electric guitars (Olorunyomi 2003: 5-6), and added a female choir that responded to his singing. This 'call and response' provided West African depth to his guitar, percussion, and horn-saturated band. He also began to sing in pidgin, forsaking both local and colonial languages. With these changes, Fela 'solved' the problem of how to make his sound 'authentically' Nigerian (and West African). His audience now heard his music as traditional and modern; local and global; particular and universal. 
João Gilberto's bossa nova provides a second example of what we might call 'innovative traditionalism', or 'global locality'. Gilberto created bossa nova by re-configuring samba. He stripped samba's stacks of percussion to a minimal rhythm which he transposed to the acoustic guitar. Additionally, he muted samba's exuberant singing, reducing it to breathless vocals skilfully projected as an unadorned voice. Finally, he gave his sound a syncopated rhythm, hinting at North American jazz but also providing jazz artists with challenges. ${ }^{3}$ Along with Antonio Carlos Jobim, Gilberto revolutionised Brazilian music.

Bossa nova - which translates as 'the new thing' - was also an 'old thing. Gilberto wanted Brazilians to recognise bossa nova as a form of samba, but one incorporating world influences. Likewise, bossa nova offered something 'authentically' Brazilian to the rest of the world, but without insularity. Musicians throughout the world felt compelled to express themselves in this new 'Brazilian' form.

Fela Kuti and João Gilberto absorbed global and local influences and produced glo$\mathrm{bal} /$ local music. ${ }^{4}$ I explore the tension between the global and the local, relying on Burke Thomason's Making sense of reification (1982). Via an exegesis of Alfred Schutz, Thomason argues that while de-reification (taking something that has been conceived as a thing and showing the process of its construction instead) is vital, we still need reification. I am suggesting that we may need to return to dreaded concepts such as 'essence' or 'authenticity' - concepts which musicologists and social theorists have laboured to dismantle. Today, this dismantling has truncated thinking, resulting in a new orthodoxy.

Could a limited embrace of 'essence' and 'authenticity' be more productive? I consider whether we can re-conceptualise 'essence' and 'authenticity' with some suppleness. Can such a re-conceptualisation moot the swings between reification and de-reification? Does shifting to 'changing essences' and 'changing global-local authenticities' make a difference? Will such a shift counter the assimilation of local music by powerful global influences? Will it release the local to move beyond a 'customary' essence? Can we hope for music that is not flattened and homogenised by the west, nor deposited in museum archives as the residue of dead 'tribes'? Can we strive for global music with local roots, and local music with global relevance?

\section{Bossa nova as samba?}

We are not going to sell [Brazil's] exotic side, of coffee and carnival. We are not going to wheel out the typical themes of underdevelopment. We are going to pass from the agricultural to the industrial era. We are going to use our popular music with the conviction that it does not only have its own character, but also a high technical level. - Tom Jobim (quoted in Reily 1996: 6)

Antonio Carlos Jobim (whom Brazilians know as Tom) credited João Gilberto with creating bossa nova. As we shall see, Jobim was not wrong; Gilberto's alterations to samba changed Brazilian music. But his changes - an altered rhythm, understated vocals, and 
a reduction of musical density - go beyond technique. What pushed Gilberto and Fela Kuti towards such changes? Did larger social issues generate their musical disaffection? I argue that Gilberto and Kuti (whom I address in the section below) responded to social problems: a desire not to be left behind developmentally, and a desire to achieve a cosmopolitan status without sacrificing particularity. ${ }^{5}$

Theorists, policy-makers, and musicians deploy music to build nations and states. In Music makes the nation (2008), Benjamin Curtis rejects the primordiality of national music. All national traditions are inventions, he argues. While his position hardly needs support in the current climate, I nevertheless provide a taste of the global context in which bossa nova and afrobeat emerged.

Gilberto spent his early years in the town of Juazeiro, Bahia, in Brazil's northeast. According to Ruy Castro's witty and precise Bossa nova: the story of the Brazilian music that seduced the world (1999), a local music lover, a Mr Emicles, travelled great distances to find records which he played for all to hear. With the help of Emicles, Juazeiro's soundscape comprised jazz greats such as Tommy Dorsey and Duke Ellington. But they also included Carlo Buti (an Italian), Gregorio Barrios (a Spaniard), Charles Trennet (a Frenchman), and Francisco Canaro (a Uruguayan-Argentine). While Gilberto's feet were far from global art currents, his ears were flooded with international sounds provided by radios and records. Gilberto's subsequent pilgrimage to Rio de Janeiro intensified that flow to include the big-band jazz orchestrations of Stan Kenton and the vocals of Frank Sinatra, Julie London, Nat King Cole, Woody Herman, Anita O’Day, Glenn Miller and Billy Eckstine.

US influence in Rio led to what one theorist calls 'Americanisation' (McCann 2004: 56). We can assess the scope of that influence by noting two developments: the first, the success of Dick Farney. This was the stage name of the vocalist Farnesio Dutra. He sang in English, and 'crooned' like Bing Crosby. Farney also adopted the 'persona of a world-weary high society playboy' (McCann 2004: 56). His 1946 hit 'Copacabana' was the 'national answer to the prayers of a good number of young postwar Brazilians' who craved 'American swing bands, crooners and vocal ensembles' (Castro 2000: 5). Farney promptly relocated to the United States and sang with top-notch jazz bands as well as notables such as Nat King Cole, Bill Evans and Dave Brubeck. A few years later, despite his successful career as an 'American singer', Farney returned to Rio where he remained a celebrity (and eventually promoted bossa nova).

The second notable development is the creation, by 1949, of 'fan clubs' dedicated to Glenn Miller and Stan Kenton, for example, by Rio's bourgeois youth. The Sinatra-Farney Fan Club, as the name suggests, honoured both Sinatra and Farney (Castro 2000: 16). Emulating the success of modern stars required an imitation of economy, polity and culture.

João Gilberto rejected imitation. With a voice like a 'song-thrush', he could render exact replications of famous singers such as Orlando Silva, who is still regarded as one of the best Brazilian male vocalists of all time. Had he not selected a different path, Gilberto could have become Brazil's 'greatest romantic singer' (Castro 2000: 40). 
To characterise Gilberto's new style, I need to say a few words about samba - the style Gilberto modified. McGowan and Pessanha (2008: 23) describe samba as a 'vibrant musical form' characterised by 'responsorial singing' and 'percussive interplay'. Here is their technical description of samba:

Samba has a 2/4 meter, an emphasis on the second beat, a stanza-and-refrain structure, and many interlocking syncopated lines in the melody and accompaniment. The main rhythm and abundant cross-rhythms can be carried by hand-clapping or in the percussion (batucada), which include a dozen different drums and percussion instruments. Samba is frequently accompanied by instruments such as the guitar and four-string cavaquinho and - less frequently brass. $^{6}$

It was samba that Gilberto transformed. Gifted with perfect pitch, Gilberto developed a nasal style so that his vocals would blend with his guitar chords. Castro describes Gilberto's voice as a trombone 'of the highest precision'. He 'made each syllable fall on every chord as if the two had originated together'. In addition, he played in one speed and sang in a different one. He sounded as if he was singing barely above a whisper, and yet he projected above party noises (2000: 92). Gilberto claimed that yoga breathing helped him develop these techniques (2000: 93). He also simplified the samba beat (Béhague 1973: 213). It was as if he reduced the 'whole rhythmic army of the samba school to just the tamborins' (2000: 105). And yet the rhythm was flexible enough to produce new developments.

Appreciating Gilberto's innovation requires a closer look at his new rhythm. The music scholar John Murphy (2006: 37) explains how Gilberto blends harmony, rhythm and lyrics as follows:

The rhythm is interesting on several levels: the melodies use a syncopated rhythm that follows the accents of the Portuguese lyrics. The guitar accompaniment, originated by João Gilberto and known as violao gago, or stammering guitar, distills the samba's energetic percussion into a playful alternation between the strong beats and syncopated chords. The chord progressions are colorful and varied, with modulations to the unexpected keys. The very sound of sung Brazilian Portuguese creates its own music.

Suzel Ana Reily (1996: 5, quoting Sergio Cabral) provides the key to explaining how bossa nova emerges from samba, and changes it:

According to Baden Powell, João Gilberto derived the upper snaps of his 'beat' from the rhythms of the tamborim, the small hand drum used in samba school percussion ensembles, while the thumb reproduced the thump of the surdo, the samba bass drum. He was able 
to produce chords with up to five tones by using the little finger of his right hand to pluck the highest string, something that had never been done before.

The thumb plays the low notes of samba's bass drum (surdo), while the plucking fingers play the role taken up by the syncopations of the higher pitched small frame drum (tamborim). ${ }^{8}$ Much like Fela, as we shall see, Gilberto moves the role of percussion to the guitar.

When Tom Jobim and João Gilberto started collaborating, Jobim lauded Gilberto's skill at singing softly and hitting precise notes. He was even more impressed with how Gilberto's guitar rhythm introduced possibilities for his composing. He believed he could arrange within that beat in ways that, in Castro's words, would mean saying 'goodbye to the dictates of conventional samba' (2000: 118).

While I have trained my ears to find the clave - predominant in West African and Afro-Cuban music - detecting bossa nova's rhythm remains difficult for me. The clave is clear and strongly repetitive in almost all West African and Afro-Cuban music. Once you find it, you can stay with it for the entire performance. Samba's rhythm too is grounded in steady repetition. But bossa nova 'is typically more varied', and 'cannot be represented by a single rhythm pattern' (Murphy 2000: 43).

In sum, bossa nova changes samba in two ways: the abundant, thick, and layered percussion is reduced to two parts on one guitar; and samba's dominant driving rhythm turns into bossa nova's subtle rhythmic variations. Jobim found his masterful compositions within this structure.

Allow me to return to the Jobim quote with which I started this section:

We are not going to sell [Brazil's] exotic side, of coffee and carnival. We are not going to wheel out the typical themes of underdevelopment. We are going to pass from the agricultural to the industrial era. We are going to use our popular music with the conviction that it does not only have its own character, but also a high technical level (quoted in Reily 1996: 6).

I take Jobim to mean three things. First, he wishes to move past the exoticism ${ }^{9}$ ge- $^{-}$ nerated by Carmen Miranda's reception, and beyond the underdevelopment associated with samba. Second, bossa nova's sophistication will move Brazilians towards the future. Third, however, Brazil will not replicate modernity's disembedded, free-floating universal abstractions. Rather, it will search for its 'own character', grounded in an aesthetic derived from its own particular place (Dibbel 2000: xi). Reily (1996: 6) expresses Jobim's negation and synthesis as follows:

Bossa nova can indeed be seen as de-exoticised Brazilian music. While drawing on various Afro-Brazilian traditions, the mellow sound of the guitar and the soft percussion highlighted their complex principles of rhythmic organization rather than their visceral qualities. João Gilberto's timid and quiet voice negated the stereo- 
type of Brazilians as an over-emotive, exuberant race, the natural products of a tropical climate, to portray them as contemplative, intimate and sophisticated. The perfection and precision with which he fitted his accompaniments to the deceptive simplicity of Tom's [Jobim's] melodic lines are comparable to the workings of a finely tuned machine. 'Chega de Saudade' [the composition that announces the arrival of bossa nova] was a masterful response to Rio's search for a new medium of popular musical expression. The land of carnival had entered the modern era.

Gilberto's and Jobim's music answers this question: how do we achieve a modern status while retaining our particular sensibility? Their musical changes serve this larger purpose.

Did bossa nova reach its goal? Critics such as José Ramos Tinhorão derided bossa nova's lack of authenticity, claiming its disruption of samba was due to 'Yankee imperialism' (quoted in Béhague 1973: 211). ${ }^{10}$ Tinhorão asserts that bossa nova 'broke decisively with the popular heritage of samba' by changing samba's rhythm (quoted in Vianna 1999: 95).

By contrast, the leading ethnomusicologist Gerard Béhague emphasises continuities between samba and bossa. Both, he claims, have Afro-Brazilian origins (1973: 209-210). He minimises jazz's influence on bossa nova, arguing that there is nothing new about foreign influences on Brazilian music. Second, he suggests that jazz's impact is less than what Tinhorão imagines: 'There are ... very few cases of direct imitation, and the only traceable trait is the highly improvised style on an implied theme of some Bossa Nova pieces that could be related to bebop' (1973: 212). ${ }^{11}$

Béhague refers to bossa nova's rhythm as balanço. This suggests an 'oscillatory, swinging motion', with 'little if any relationship with the swing quality of jazz' (1973: 212). ${ }^{12}$ Caetano Veloso contrasts bossa nova with the unrepentant imitations of Dick Farney and Johnny Alf, regarding the latter's music as 'an alienation of the underdeveloped middle class whose goal it to become like its counterpart in the dominant country' (1999: 95). But he finds no such danger in bossa nova; 'João Gilberto really understands the mysterious idiosyncrasy of samba and is the best among Brazilian musicians of all time, at playing with it' (1999: 95).

In 1959, Sarah Vaughan and Nat King Cole performed in Rio. Both showed an interest in bossa nova, with Cole performing with Sylvinha Telles as well as collecting material for his Latin tinged records (Castro 2000: 206). While visiting Rio in May 1960, Lena Horne performed a duet with Gilberto, singing his 'Bim-bom' in Portuguese. She had learnt this song by listening to Gilberto's album, and was keen to meet him (2000: 205). Later that year, in São Paulo, Sammy Davis Jr performed with what would later become the Tamba Trio's percussion section. Perhaps the most important visitor in 1960 was the guitarist Charlie Byrd, who took bossa nova back to the United States (2000: 241). By the time Tony Bennett arrived in Brazil in 1961, Gilberto's album Brazil's Brilliant João Gilberto had been released in the United States. Bennett's familiarity with Brazil's new music predated his arrival. 
In July 1961, a 'battalion of jazz enthusiasts' arrived in Rio and Sao Paulo for festivals (2000: 241). Among them, Herbie Mann stands out for recording with Brazilian musicians in Rio. His comfort resulted from already having played with João Donato, a bossa nova stalwart who had moved to California. By March 1962, Stan Getz and Charlie Byrd had released their version of 'Desafinado', selling more than a million copies (2000: 24142). Later that year, in November, João Gilberto, Jobim and others famously performed at Carnegie Hall. When bossa nova arrived in New York City, stars such as Peggy Lee, Dizzy Gillespie and Miles Davis sat in the audience.

Many regard the Carnegie Hall concert as bossa nova's greatest triumph. But Castro's narrative offers a deferred climax. Four years later, in 1966, while at the Veloso Bar in Rio, Jobim received a phone call from Frank Sinatra seeking a recording collaboration. Castro (2000: 326) draws out the event's significance:

In December 1966, if someone told you that you had a phone call, and Frank Sinatra was on the other end of the line, 10132 kilometres away, it would really make you stop and think. How is it possible to explain to today's reader exactly what that meant back then? There are no artists of equivalent stature in show business today. None of the post-Sinatra megastars ever managed to accumulate the same amount of power, prestige, and inaccessibility - all at once... Sinatra was still the biggest popular singer in the world in 1966. . This was the man who was phoning Tom Jobim at the Veloso.

The circle that started in the mid-1950s with the Farney-Sinatra Fan Club now enclosed those who earlier could not have envisioned becoming Sinatra's collaborators. Castro's description of the recording session between Sinatra and Jobim concludes: 'The victory was not just his, but for the whole of bossa nova as they had secretly conceived it, a million dreams ago' (2000: 331). He then proudly lists the US artists who have recorded bossa nova records. The heft and length of the list takes my breath away:

Tonny Bennet, Nat 'King' Cole, Perry Como, Vic Damone, Billy Eckstine, Johnny Hartman, The Hi-Los, Jackie \& Roy, Al Jarreau, Johnny Mathis, Mark Murphy, Bobby Short, Mel Torme, Frank Sinatra, Rosemary Clooney, Dardanelle, Doris Day, Blossom Dearie, Ella Fitzgerald, Eydie Gorme, Peggy Lee, Julie London, Carmen McRae, Hellen Merrill, Anita O’Day, Sarah Vaughan, Oscar Peterson, Erroll Garner, Earl Hines, Stephane Grapphelli, Percy Faith, Enoch Light, Billy Vaughn, Herb Alpert, Ray Anthony, The Ray Charles Singers, John Williams \& the Boston Pops. . And contemporary singers like Susannah McCorkle, Karrin Allyson, Joyce Breach, Ann Burton, Rebecca Kilgore, Kristin Korb, Yvonne Roome, Daryl Sherman, and the Nancy Marano-Ed Motero duo (ibid: 333).

I have heard most of these artists. But I did not know how spectacularly bossa nova's wave splashed on the world stage. 


\section{Afrobeat's modern traditionalism}

'In 1969 I was completely almost unintelligent because I had no original African contribution to make ...' ${ }^{\prime 3}$ - Fela Kuti (quoted in Veal 2000: 75)

'I must identify myself with Africa. Then I will have an identity' Fela Kuti (quoted in Moore 1982: 75)

The musical Fela! played off-Broadway and then on-Broadway from 2008 to 2011. The show launched a world tour after being nominated for eleven Tony awards, and playing to packed houses. With France's re-mastering and re-release of 45 of Fela's albums, the rise in print materials, and the proliferation of afrobeat bands, we are experiencing a global revival of Fela's music.

Fela Kuti (1938-97) was born to a prominent family. He was trained in western classical musical from a young age. Traditional and popular West African music further shaped his vision (Stewart 1992: 121). African diasporic popular music and art music (jazz) constitute a third influence. Michael Veal's definitive Fela: the life and times of an African musical icon (2000) specifies Fela's influences: ${ }^{14}$ James Brown and John Coltrane (United States), Ambrose Campbell (Nigeria), the highlife composers E T Mensah (Ghana) and Victor Olaiya (Nigeria), and what Veal (2000: 12) calls 'neotraditional' Yoruba musicians such as the apala singers Haruna Ishola and Ainla Omowaura (both Nigerians).

Fela himself cites Louis Armstrong, who toured West Africa in 1956, Frank Sinatra, and Louis Prima as formative (Veal 2000: 41-2). While in London, Fela expanded his range by listening to jazz greats such a the trumpeters Miles Davis, Lee Morgan and Clifford Brown; the pianists Red Garland, Wynton Kelly and Herbie Hancock; and the saxophonists Charlie Parker, John Coltrane and Harold Land.

The pivotal encounter, however, was during his 1969 United States tour when he met Sandra Smith, a former Black Panther. Fela had coined the term 'afrobeat' prior to this encounter, but it had little content (Veal 2000: 11). Veal first describes afrobeat as an 'African-American influenced variant of the Nigerian dance-band highlife tradition', and then as a 're-Africanised form of African-American funk music' (2000: 11). Later, Veal (2000: 13) counts afrobeat as 'a premier Afrocentric dance genre of the post-World War Two era' - along with reggae, rap, salsa, funk, calypso, soukous, juju and mbaquanga. Understanding Fela's synthesis, therefore, requires discussing highlife as well as funk.

Highlife originated in the late $19^{\text {th }}$ century, with its roots in the marching bands that emerged in Anglophone West African cities like Lagos in Nigeria and Accra in Ghana. Performing in highlife bands required the skills and finances to play European brass, string, and woodwind instruments. As a result, this music is associated with the upper classes - people whose opulence gave them a 'high life' (Veal 2000: 35-6). Ballroom dances such as waltzes, foxtrots, and two-steps as well as various forms of concert music were part of the highlife repertoire. But things changed dramatically in the 1940s with the arrival of African-Cuban dance music. The Rumba, mambo, and cha-cha found a home in 
sub-Saharan Africa. The key figures in this diffusion were the Ghanian E T Mensah and his band The Tempos, as well as the Nigerian Bobby Benson who developed dance-based highlife from a 'mixture of Afro-Caribbean and indigenous elements'. This new highlife reached its zenith in the 1940s and 1950s (Veal 2000: 36). ${ }^{15}$

We have previously noted the influence of Afro-Cuban music - what Veal calls the 'modern, cosmopolitan Afro-Latin recycling of African sounds' (2000: 36). Is Afro-Cuban diffusion an internal or external influence? We may deem it as within the African Diaspora, as the return of West African music to itself via the Caribbean. Or we may observe the familiarity, but still count it as external. Either way, it may be more apposite to trace the details of how all this happened. Veal recounts that Cuban music was crucial to the Senegalese Francophone dance style known as mbalax. And the Congolese rhumba took its name from the Cuban rumba. In Sierra Leone, when Gerald Pine heard Latin American music, he changed his name to Geraldo Pino and sang the new style with imagined Spanish lyrics (Veal 2000: 41). The Cuban influence was that strong.

Funk was equally influential, but arrived later. James Brown developed funk in the 1960s by combining his 'gospel-driven vocals' with 'jazzy horn arrangements', all on top of a 'highly syncopated percussive rhythm scheme' (Veal 2000: 11). We know that in the 1960s United States, James Brown's funk catalysed the black rediscovery of an African heritage. Less well known is funk's immense popularity in West Africa (Veal 2000: 12). Brown's percussive structure demonstrates similarities to the traditional music of West Africa. To summarise, before Fela studied in London from 1958 to 1963, the four influences on his musical life were traditional West African music, highlife, the western art tradition, and funk.

Veal discusses two types of Africans who studied in Europe. The first were dedicated to perfecting western art music. Upon their return, they performed in chamber groups, choirs, and symphony orchestras (2000: 39-40). Fela fell into the second category of students, who wished to infuse western theory and technological knowledge in popular West African styles (2000: 40). Formerly colonised people from all over the world filled London at this time. Musical fertilisation was especially strong among Africans and West Indians who brought 'calypso, highlife, ska, mambo, jazz' to their interactions (2000: 40).

Once in London, Fela fell under the influence of jazz (Stewart 1992: 117). Says Fela:

I played a lot of jazz in the beginning of my career because it had cultural information that enriched my mind ... Coltrane, Miles, Sonny Rollins, that era, because I found a heavy relationship between that music and my culture. . . [Later], I used this knowledge to penetrate into the culture of my people (quoted in Veal 2000: 41).

Jazz strongly influenced the African musical scene, particularly highlife (Olorunyami 2013: 216). This effect waxed during the swing band and big band jazz era (in the 1940s and 1950s), and waned when bebop and then free jazz moved away from metre and harmony. For West Africans, jazz meant large musical ensembles deploying horns, and any ensemble or genre relying on improvisation (Veal 2000: 42). 
Reciprocally, many US jazz musicians in the 1960s and 1970s sought to revitalise their musical and cultural heritage by travelling to Africa. Randy Weston, Art Blakey, Herbie Mann (also present in Rio during the bossa nova period), and Donald Byrd incorporated African instruments, African musicians and African themes (Veal 2000: 42). ${ }^{16}$

When Fela returned from London in 1963, he found Nigerians building a new nation for which highlife served as national music (Olaniyan 2004: 8). Meanwhile, jazz was considered the 'emergent cosmopolitan art music' of the world (Veal 2000: 49). Unsurprisingly, Fela's first band, Koola Labitos, combined highlife with jazz (Moore 1982: 73). But his Lagos audience was accustomed to highlife's openness and lightness. They found Fela's music 'too busy, dense, and aggressive', despite Fela's acclaim as the best Nigerian jazz musician. The accolade was double-sided, recognising the 'complexity of his music' but also its 'distance from ... popular tastes' (Veal 2000: 54).

Determining 'authenticity' was also a concern at the time. Eventually, highlife's upper-class association and connection with modernity became a liability. While juju artists - of which Sunny Ade is the leading exponent - used electric guitars, they did not use written music, wear western clothes, or use woodwinds. Instead, they wore traditional garments, used 'indigenous instruments with deep cultural significance such as the talking drum,' and operated within 'well-defined ethnic spheres, economic networks and stylistic norms' (Veal 2000: 56). Thus 'juju groups, and not highlife groups ... were identified as culturally "authentic" ' (2000: 56).

The rise of funk and soul also contributed to highlife's decline. Alongside James Brown, soul artists such as Wilson Pickett, Aretha Franklin and Otis Redding became well known. Not everyone welcomed the 'foreign' invasion. Like Tinhorão's response to bossa nova, some resented the foreign influence. Two quotes give us this sense. The first is from the Nigerian Daily Times:

How on Earth a Nigerian ... could condescend to 'soul'. . As the Nigerian James Browns wish us to believe, this soul thing is more than a dance. It is a fraternity, it is black smoothness, negroid rhythm ... the lot. I ask you - what is negroid soul? The black Africans in Brazil use African musical instruments and really sweat it out to Yemoja, the long forgotten Yoruba goddess... What the American Negros are doing, and converting young Nigerians to, is a perversion of the African beat (quoted in Veal 2000: 59; emphasis added).

J K Obatala, an African-American living in Ghana, rejected the very term 'soul'. Like 'Negritude' before, he felt 'soul' was uncritical of an essentialised blackness. For Obatala (1971: 8-12), soul represented little more than a sound-track for US capitalism, delivered by friendly black faces. But soul music gained ground, as critics remained a minority. Despite the hard work and some success of Fela's band, it failed to navigate these trends, and Fela was frustrated by popular imports (Durotoye 2003: 175; Coker 2004: 21).

Afrobeat was Fela's response to this frustration. He aimed at 'a middle path - asserting his individuality while distancing himself from both soul and highlife' (Veal 2000: 
62). Speaking in temporal terms, we might say he was dissatisfied both with the external present, namely soul, and the internal but dated past, namely highlife. While Fela had readied 'afrobeat' the concept, it was not be until his US encounter with Sandra Smith that he began to realise his vision.

Somehow, the band arranged a visit to the US in 1969. However, after many months of travelling and performing, Fela was deflated by their lack of success (Veal 2000: 68). By chance, he met Sandra Smith, a former singer and a Black Panther. Her mentoring reshaped his world view as she introduced Fela to the works of Stokely Carmichael, Angela Davis, Martin Luther King, Elijah Muhammad, Jesse Jackson and Malcolm X. Fela imbibed black nationalism and pan-Africanism. As Smith says with some irony, 'It was like I was turning him on to Africa' (quoted in Veal 2000: 71). Fela renamed his band Nigeria 70, and produced what he considered his first 'afrobeat' composition - 'My Lady's Frustration' dedicated to and inspired by Sandra.

Fela started to reconcile jazz, highlife, and funk elements in his music. His diagnosis of his previous troubles targets an absence of African specificity: 'In 1969 I was completely almost unintelligent because I had no original African contribution to make. ... (quoted in Veal 2000: 75). And: ' ... I really began to see that I had not played African music. I had been using jazz to play African music, when really I should have been using African music to play jazz' (Collins 2009: 135).

Fela made three vital changes that, in Veal's words, 'intensified the traditional feeling' in his music and constituted his 'African contribution' (Veal 2000: 93; Olorunyami 2003: 216). He included a 'tenor guitar' that plays a 'repeating, single-note staccato figure in the middle register' (Veal 2000: 93) and serves as a 'contrapuntal voice' between the bass guitar and what Veal calls the 'rhythm guitar.' ${ }^{17}$ This change 'accentuated the tightly hocketed, pre-composed rhythmic structures' (Veal 2000: 93). Most African styles, especially highlife, use guitars for both improvising and supporting functions; guitars solo, but they also constitute the rhythmic fabric. ${ }^{18}$ Afrobeat's three guitars - bass, tenor and alto - do not improvise. Instead, they play interlocked, strictly repetitive patterns. Eliminating the improvising guitar allowed Fela to distance afrobeat from highlife. Fela's afrobeat separates those instruments providing the foundational percussive structure from the improvising instruments: guitars and small percussion create repetitive structures, while horn instruments and Fela's vocals improvise. This division reproduces the traditional drum ensemble organisation: some drums repeat patterns, while other drums play variably within those patterns. Separating soloing from non-soloing parts 'replicated the structure of traditional drum ensembles' (Veal 2000: 94). These changes give afrobeat its hypnotic, mesmerising, and propulsive effect, while also providing a traditional sensibility (Collins 2009: 120).

Second, Fela introduced a six-woman chorus creating contrast with his 'smoky tenor'. More important, his vocal interactions with the chorus produced a variety of call-and-response patterns (Collins 2009: 110). Because much African music is saturated with call-and-response interactions, implementing the chorus gave Fela's sound a traditional quality. Third, Fela sang in pidgin instead of standard English, or local dialects like Yoruba. Pidgin allowed him to reach the working classes and audiences beyond Nigeria (Ikue- 
nobe 1994: 3; Olorunyomi 2003: 68). Pidgin also allowed Fela to sing percussively; freeing him to 'dart in and around the rhythm in a strongly jazz inflected fashion' (Veal 2000: 95).

By contrast, aspects of his modernism included a harmonic stress rooted in the modalism of jazz and western art music; a pre-structured and 'tight' ensemble borrowed from James Brown's funk; and a western composing style in which 'specific music accompanies specific lyrics', and in which the form is predetermined with little room for change across performances (Veal 2000: 96). In this way, Fela synthesised the global, cosmopolitan and contemporary with the local, indigenous and traditional.

\section{Authenticity after de-reification}

'... reification and even a kind of inauthenticity is essential. Without it, the interpreter has no bearings.' - Burke Thomason (1982: 94)

'.. if we mean by authentic honest or sincere in a setting of commercial jive; if we mean knowing one's own history and being able to map the traditions of sound that invented it rather than passing off shtick as a novelty of style, then it is hard to see why authenticity is not still valid.' - Timothy Brennan (2008: 86)

Fela Kuti and João Gilberto propelled their music onto the world stage while retaining particularity. They translated and synthesised the external and the internal, producing an 'authentic' sensibility. Gilroy (2005) terms this synthesis the 'trans-local'. The geographers Connell and Gibson (2004: 357) recognise how Gilroy's 'trans-local' assumes that the 'global and local are relational rather than oppositional'. Nevertheless, they stress how global processes confound authenticity, making it a reification and an error. Or those who use 'authenticity' act tactically: 'some seek to strategically position themselves as locally authentic; some seek to embody or reconnect with ethnic or national traditions and histories; others seek to become transnational performers' (2004: 358). Despite their understanding of Gilroy's 'trans-local' as relational, Connell and Gibson treat the 'local' and the 'transnational' as a dualism.

Thus these authors diminish the 'trans-local', preferring what Gilroy (1993: 80) calls the new anti-essentialist orthodoxy, which cinches arguments by exposing reified thinking and demonstrating the presence of essentialism. Gilroy (1993: 102) rejects such cinching. Instead, his 'anti-anti-essentialism' points to the fertile ground between reified essentialisms and the new orthodoxy's cant:

Music and its rituals can be used to create a model whereby identity can be understood neither as a fixed essence nor as a vague and utterly contingent construction to be reinvented by the will and whim of aesthetes, symbolists, and language gamers.

Like Gilroy, Timothy Brennan (2008) defends 'authenticity' by arguing that the anti-essentialist orthodoxy ignores 'authenticity's' pervasiveness. He then asks (2008: 85) whe- 
ther authenticity can serve central needs. Below, I produce a brief survey of reification, and then return to Brennan's question.

Theorists of reification exhibit three tendencies: they locate errors in thinking that their analysis corrects; they sympathise with the reifying impulse, demonstrating its uses; and they balance these two poles. We can differentiate among theorists by where they place their emphasis.

In an entry in the Dictionary of sociology, John Scott and Gordon Marshall (2009) define reification as the 'error of regarding an abstraction as a material thing, and attributing causal powers to it'. We conflate the material described by the concept with the concept itself. Similarly, for Daniel Levine (2012: 15), 'reification is a ... kind of forgetting' during which we lose 'the distinction between theoretical concepts and real-world things which they mean to describe'. He concedes that 'all theory ... relies on forgetting', but stresses how reification 'thingifies sentient beings' (2012: 15 -16). In four concise pages, Berger and Luckman (1966: 89-92) write: 'Reification is the apprehension of human phenomena as if they were things'. Reification is the 'apprehension of the products of human activity as if they were something else', such as facts of nature, the results of cosmic laws, or expressions of divine will. Reification implies that we are 'capable of forgetting' our 'authorship of the human world'. Such a world is 'dehumanised'. Re-humanising and de-reifying depends on understanding that 'the social world was made by men - and can be remade by them' (1966: 89). Berger's and Luckman's exposition leans on Berger's prior work with Pullberg.

Berger and Pullberg (1965) introduce reification (verdinglichung) via a synoptic history of thought. They start with Hegel and Marx, though they admit that neither employs the term. For Hegel, humans first 'exteriorise' themselves and then 'lose themselves' in things they create. They posit those things not as their creations but as 'in-itself-others'. For Berger and Pullberg, this positing creates 'alienation' and 'reification'. In Hegel's third moment, humans return these 'in-itself-others' to themselves. In this return (1965: 198), '[a]ll alienation, and its attendant reificational thinking, is surmounted in the absolute knowledge of the philosopher wherein Spirit is fully transparent to itself, and knows itself in its otherness while remaining with itself'. First exteriorisation, then reification, and, lastly, de-reification.

Marx critiques and overturns Hegel's delimiting of de-reification to the realm of thought. For Marx, Hegel's idealism flattens and erases actual material process, especially human suffering. Marx fought Hegel's mystifications, but also railed against political economy's 'objectivistic scientism'. Capitalism causes humans to forgo direct social contact that is replaced by relating via commodities; capitalism produces an asocial sociality where things mediate social relations. Eventually, a 'mathematically expressible' science of objects, 'political economy' (or today economics), emerges to explain the benefits of a thing-mediated asociality. Marx's Capital elucidates these themes in the famous 'fetishism of commodities' section. Berger and Pullberg (1965: 199) highlight fetishism's implications as follows:

There are not only fetishized commodities, but there is also fetishized power, fetishized sexuality, fetishized status. Just as the fetishism 
of commodities finds its theoretical expression in a reified political economy (or, to use a more contemporary term for this science, in reified economics), so the other species of fetishization are theoretically formulated and thereby mystified in reified political science, reified sociology, reified psychology, and even scientistic philosophy.

By regarding reification as a correctable error, Berger and Pullberg retain much of Marx's sensibility. ${ }^{19}$ 'Reified social process', they say, 'are intrinsically alienating and de-humanizing' (1965: 208). While reification is not universal across history and cultures, 'it is still the case that reification constitutes the de facto reality of most socio-historical situations' (1965: 208; emphasis added). This observation returns us to Brennan's provocative question: if reification is not universal, how do we account for its seeming ubiquity? ${ }^{20}$

Burke Thomason's exegesis (1982) of Alfred Schutz's work responds to this challenge. Thomason asks: is reification useful? Might it be necessary, or essential? Is that why we find it everywhere? Is that why de-reification seems so difficult?

Thomason starts with reification's usual meaning, and then investigates an alternative (1982: 88). Typically, he writes, we understand reification as a process 'whereby various aspects of experience come to acquire a kind of inappropriate ontological fixedness'. Reification means thing-ification: 'the attribution of facticity, concreteness, autonomy, impersonality, objectivity, externality ... to things that are reified'. Behind this meaning lurks an 'epistemological or ontological judgment'. The 'thing-ification', or attribution of 'facticity', are errors: 'the things reified [are not the] concrete, autonomous, inert facticities they are taken to be'.

The Marxian tradition emphasises this ontological/epistemological judgment. But, while Berger and Pullberg are inspired by this tradition, their analysis brackets the verdict. Thomason and Schutz also defer this conclusion. Thomason (1982: 7) sets aside reification as errors involving 'bad faith', 'collective inauthenticity', or 'curable distortion'. Instead, he takes up reification as a 'necessary and inevitable prerequisites of any social order'. How so?

Humans, he notes, are overwhelmed by life's diversity and flux (1982: 94). Reification suppresses diversity, reduces flux, and creates order. A world without reification (or a world of pure de-reification) is, in Schutz's words, 'not a world of being, but a world that is at every moment one of becoming and passing away' (quoted in Thomason 1982: 91). We cannot live 'meaningfully [and] consciously', Thomason believes, 'in a world of pure becoming' (1982: 94). Institutions provide 'ready-made channels' or 'grooves' for conduct. These patterns reduce diversity, flux and choice. To help us understand the stakes, he quotes Schutz as follows:

Our relationship with the social world is based upon the assumption that in spite of all individual variations the same objects are experienced by our fellow men in substantially the same way as by ourselves and vice versa, and also that our and their schemes of interpretation show the same typical structure of relevances. If this 
belief in the substantial identity of the intersubjective experience of the world breaks down, then the very possibility of establishing communication with our fellow men is destroyed (1982: 88).

Thomason (1982: 106-7) admits that our reifications constitute 'self-imposed dominations which replace human powers', and that our constructions 'constrain and channel' us as a result. Nevertheless, reification allows us to grasp the world as 'shared' - 'the same for you, for me, and for everyone' (1982: 91). Without reification, we would 'lack the common world of stable meanings 1982: 94). For Thomason, 'reality resides in this reifying consensus', not in an 'ontologically proper apprehension of the world' (1982: 110).

Yes, we create the world we make. But we create it as a reified world. For theorists, this means:

We can become aware ... of the need for actors in daily life precisely to deny, ignore, forget, and disregard the very constructionist perspective that allows us, as social scientists, to see what they do as a matter of 'denying,' 'ignoring', 'forgetting' and 'disregarding' (Thomason 1982: 164).

Thomason (and Schutz) argue that a less judgmental attitude towards those we study, and greater theoretical rigour, facilitate the discovery of reification's usefulness, persistence and indispensability. ${ }^{21}$

We needn't commit fully. We can suspect those who stress order over justice, justify the status quo, and undermine critical analysis. Nevertheless, Thomason's critique impresses me: he challenges us 'to preserve the humanising potential of constructionist theory', but 'without allowing that theory itself to assume inhuman dogmatic proportions' (1982: 7). Daniel Levine (2012: 228) also cautions against new orthodoxies:

If all thinking relies on reification, and if one-off acts of conceptual debunking merely replace old reifications with new ones, then [reification's] management means aiming particular, carefully chosen, fact-value positions to either 'knock out' others, or else to hold them in careful equipoise, such that neither hardens into a new repressive orthodoxy.

Sustaining the humanising potential of 'new orthodoxies' remains a challenge.

What does our detour through 'reification' provide for our consideration of bossa nova and afrobeat? It means that, when we expose reification as an error, we mistake the beginning for the end of our analysis. Depending on the context, reification may or may not be wrong. A deeper analysis addresses the reasons for reification: Why did some construct 'samba' and the 'Brazilian nation' to fit together? Why were bossa nova and afrobeat constructed at all? Why did some receive them as 'authentically' Brazilian or Nigerian? Why were others agitating against these constructions? These are the stories we need to tell. 
We can now revisit Brennan's question: why is the need for authenticity so central? Connell and Gibson (2004: 358) point to de-territorialisation as the answer: 'the rise of world music elegantly demonstrates how de-territorialisation has resulted in, and necessitated, an exaggerated sense of locality and cultural distinctiveness'. Gilroy (1993: 101) responds similarly: ' ... the invocation of tradition may itself be a distinct, though covert, response to the destabilising flux of the post-contemporary world'.

Whatever name we give them - de-territorialisation, destabilising flux, globalisation, capitalism, or modernity - these forces threaten to de-place us. And while we can reject any 'inherent coherence between culture and space' (Connell and Gibson 2004: 357), this theoretical knowledge seems powerless when humans face the need to locate specific roots. As Hebdige (quoted in Connell and Gibson 2004) might say, knowing there is 'no such thing as a pure point of origin, least of all in something as slippery as music' falls short of stopping our search for origins and roots. Theoretical fiat fails to eliminate this need.

We can, however, explore the work those roots perform by excavating their soil. By so doing, we may learn that such roots need not be fixed, frozen, or essentialised. As Hebdige (quoted in Connell and Gibson 2004) evocatively suggests, they can vary: 'the roots themselves are in a constant state of flux and change. The roots don't stay in one place. They change shape. They change color' Accordingly, Gilroy (1993: 101) thinks of cultural and musical traditions 'as a changing as opposed to an unchanging same'. Hebdige's 'changing roots' and Gilroy's 'strategic essentialism,' 'flexible essentialism,' and 'changing same' (1993: 31, 99, 101) excavate common ground. Brennan (2009: 85) harvests these fruits to present fresh answers to the question: 'what is authentic?'

With 'changing essences' or changing 'trans-locals', we can resist global influences without essentialising local creativity as 'tribal' or 'customary. Music needn't suffer bulldozing imperialism, nor museum mummification. We can have innovating locations. We can have global music with local roots, and local music with global relevance.

If João Gilberto and Fela Kuti participated in the 'error' of authenticity, they understood their 'error' as a necessity. Exploring the tension between reification as 'error' and 'necessity' allows us to find remainders. These remainders push us to declare ourselves as partisans in aesthetic, cultural and musical conflicts. The fight to retain and cultivate the planet's diverse social and musical life strikes me as no less important than the struggle to contain wars, avert ecological disasters, and promote human rights. ${ }^{22}$ Thoughtless authenticity freezes essentialisms, while authenticity's dismissal negates place specificity. Authenticity after de-reification produces a vitality that may linger.

In closing, I return to DAM's artistic energy. Even as their lyrics fight against assimilation, I wonder if their form succumbs to a deeper (self)-colonisation. Is their vitality not better served, I want to ask, by creating forms more aligned to their own trans-locality? To a musical form and cultural history traceable to the places from which their energy emerges? Would locating their specificity make a greater contribution to the universal? What might they produce when infused with the aspirations exhibited by bossa nova and afrobeat? 


\section{Notes}

1 For 'authenticity' as a false problem, see Potter (2010).

2 For musicological discussions of 'authenticity', see Murphy (2007: 33-34); Moore (2002: 209-223); Johnson (2000: 277-86); and Bohlman (2000: 411-36).

3 See the DVD directed by Walter Salles entitled 'Bossa nova: music and reminiscences', Video Filmes/ Cameras Contentiales, 1993.

4 For more on global/local, also expressed as 'glocal', see Biddle and Knights (2013: 19-38).

5 On overcoming the stigma of 'underdevelopment', see Zarakol (2011). On how composers, musicians and communities address social problems through their music, see Dinerstein (2003); Curtis (2008); Vianna (1999); and Finkelstein (1960).

6 See also Roberts (1998: 78) and Murphy (2007: 7). While I have no troubles with this description, I also hear samba as the oppositional juxtaposition and integration of two modes. Its singing strikes me as focused on melodies, harmonies, and lyrical content. The non-singing instruments, on the other hand, fit Olly Wilson's six characteristics of African-derived music: an abundance of 'call and response' structures; a heterogeneous sound ideal; percussive tension; a percussive manner of playing all instruments; a high density of events; and an integration of bodily response, especially dance, into the performance. I also hear some overlap between the two modes - the singing is full of 'call and response' patterns. See Wilson (1983: 1-22); Wilson (1974: 3-22); and Weinrobe and Inayatullah (2005: 239-62).

7 See also Béhague (1973: 213).

8 See also Murphy (2007: 39-40).

9 On Carmen Miranda, see the excellent essay Veloso (2001).

10 See also Vianna (1999: 95).

11 See also Jobim's minimisation of the influence of jazz in Reily (1996: 9).

12 See also Béhague (1980: 440).

13 Olorunyomi (2003) also provides a deep understanding of Fela’s music and its context.

14 See also Collins (2009: 59).

15 See also Olaniyan (2004: 8) on highlife as the soundtrack of the Nigerian nation.

16 See also Olaniyan (2004: 175).

17 I prefer the term 'alto guitar' to 'rhythm guitar'. Because all guitars perform rhythmic functions, we need to distinguish them by their pitch.

18 As in Stephen Osita Osadebe's music.

19 Even if they do not reject, condemn or critique the political structure that produces those errors. See Thomason (1982: 127).

20 This question is also the beating but silent pulse of Berger's and Pullberg's essay.

21 Why do we reify? Moving from sociology to psychology, I might say: Perhaps we reify because we cannot face that we construct ourselves as slaves; cannot face or explain how the world we have created enslaves us and others; cannot face our own complicity in making such a world, nor the coerced nature of our complicity. In Lacanian language, reification may be conceived as a way of sustaining an orbit around the 'real'.

22 Readers may misread my emphasis on bossa nova and afrobeat as a bias towards local music that arrives on the world stage. What then about local music that, for various reasons, stays local? While I do not wish to underestimate the resilience of local traditions, I worry about their dynamic longevity in the face of more powerful economic/aesthetic currents. I am concerned with routes to viability, and means to cultivating differences that thrive. To my ears, bossa nova's and afrobeat's success was achieved within local specificity. If so, they provide viable models for those who strive for world recognition but are neglected by those currents. 


\section{References}

Béhague, Gerard. 1973. 'Bossa \& bossas: recent changes in Brazilian urban popular music'. Ethnomusicology 17(2): 209-233.

1980. 'Brazilian musical values of the 1960s and 1970s: popular urban music from bossa nova to tropicalia.' Journal of Popular Culture 14 (3): 437-52.

Berger, Peter L and Thomas Luckman. 1966. The social construction of reality. New York: Anchor.

Berger, Peter L and Stanley Pullberg. 1965. 'Reification and the sociological critique of consciousness.' History and Theory 4(2): 196-211.

Biddle, Ian and Vanessa Knights. 2013. 'Introduction: national popular musics: betwixt and beyond the local and global'. In Ian Biddle and Vanessa Knights (eds), Music, national identity and the politics of location. Burlington, VT: Ashgate.

Bohlman, Philip V. 1993. Musicology as a political act. The Journal of Musicology 11 (4): 411-436.

Brennan, Timothy. 2008. Secular devotion: Afro-Latin jazz and imperial jazz. New York: Verso.

Cabral, Sergio. n.d. 'Em busca da perfeição'. In A Chediak (ed), Songbook: bossa nova, vol 2. Rio de Janeiro.

Castro, Ruy. 2000 [1990]. Bossa nova: the story of the Brazilian music that seduced the world. Translated by Lysa Salsbury. Chicago: A Capella.

Coker, 'Niyi, Jr. 2004. A study of the music and social criticism of African musician Fela Anikulapo-Kuti. Lewiston, NY: Edwin Mellen.

Collins, John. 2009. Fela: kalakuta notes. Amsterdam: KIT.

Connell, John and Chris Gibson. 2004. World music: deterritorializing place and identity. Progress in Human Geography 28 (3): 342-61.

Curtis, Benjamin. 2008. Music makes the nation: nationalist composers and nation building in nineteenth-century Europe. Amherst, NY: Cambria.

Dibbel, Julian. 2000. 'Foreword. In Bossa nova: the story of the Brazilian music that seduced the world. Translated by Lysa Salsbury. Chicago: A Capella.

Dinerstein, Joel. 2003. Swinging the machine: modernity, technology, and American culture between the word wars. Boston: University of Massachusetts.

Durotoye, Yomi. 2003. 'Roforofo fight: Fela's resistance of domination'. In Trevor Schoonmaker (ed), Fela: from West Africa to West Broadway. New York: Palgrave.

Finkelstein, Sydney. 1960. Composer and nation: the folk heritage of music. New York: International Publishers.

Gilroy, Paul. 1993. The black Atlantic: modernity and double consciousness. Cambridge, MA: Harvard.

2005. 'Could you be loved? Bob Marley, anti-politics and universal sufferation'. Critical Quarterly 47 (1-2): 226-245.

Ikuenobe, Polycarp. 1994. 'African aesthetics and the music of Fela A Kuti: a semiotic analysis'. Literary Griot 6 (2): 1-13.

Johnson, Sherry. 2000. 'Authenticity: who needs it?' British Journal of Musical Education 17 (3): 277-86. 
Levine, Daniel J. 2012. Recovering international relations: the promise of sustainable critique. New York: Oxford.

Lewis, Leslie. 2005. 'Naming the problem embedded in the problem that led to the question, "who shall teach African Literature?"' In Lisa A Long (ed), White scholars/African American texts. New Brunswick: Rutgers.

Mackey, Nathaniel. 1992. 'Other: from noun to verb'. Representations 39: 51-70.

McCann, Bryan. 2004. Hello, hello Brazil: popular music in the making. Durham, NC: Duke.

McGowan, Chris and Ricard Pessanha. 2008. The Brazilian sound: samba, bossa nova, and the popular music of Brazil. New Jersey: Temple University Press.

Moore, Allan. 2002. 'Authenticity as authentication'. Popular Music 21(2): 209-223.

Moore, Carlos. 1982. Fela, Fela: this bitch of a life. London: Allison \& Busby.

Murphy, David. 2007. 'Where does world music come from? Globalization, Afropop and the question of cultural identity'. In Ian Biddle and Vanessa Knights (eds), Music, national identity and the politics of location. Burlington, VT: Ashgate.

Murphy, John P. 2006. Music in Brazil: experiencing music, expressing culture. New York: Oxford.

Obatala, J K. 1971. 'Soul music in Africa: has Charlie got a brand new bag?' Black Scholar 20: 8-12.

Olaniyan, Tejumola. 2004. Arrest the music! Fela and his rebel art and politics. Bloomington: Indiana University Press.

Olorunyomi, Sola. 2003. Afrobeat! Fela and the imagined continent. Trenton, NJ: Africa World Press.

Perrone, Charles A and Christopher Dunn (eds). 2001. Brazilian popular music and globalization. Gainsville: Florida.

Potter, Andrew. 2010. the authenticity hoax: how we get lost finding ourselves. New York: Harper Collins.

Reily, Suzel Ana. 1996. 'Tom Jobim and the bossa nova era'. Popular Music 15 (1): 1-16.

Roberts, John Strom. 1998. Black music of two worlds: African, Caribbean, Latin, and African-American traditions. New York: Schirmer.

Salles, Walter. 1993. 'Bossa nova: music and reminiscences'. Video Filmes/Cameras Contentiales.

Scott, John and Gordon Marshall. 2009. 'Reification'. Oxford Reference Online. http://www. xfordreference. om/view/10. 093/acref/9780199533008. 01. 001/acref-9780199533008-e1906? rskey=6sNfAD\&result=1907 Accessed on 20 May 2015.

Stewart, Gary. 1992. Breakout: profiles in African rhythm. Chicago: University of Chicago Press.

Thomason, Burke. 1982. Making sense of reification: Alfred Schutz and constructionist theory. Atlantic Highlands: Humanities Press.

Tinhorao, Jose Ramos. 1966. Musica popular: um tema em debate. Rio de Janeiro, Editora Saga. 1969. O samba agora vai: a farsa da música popular no exterior. Rio de Janeiro: JCM Editores.

Veal, Michael. 2000. Fela: the lives and times of an African musical icon. Philadelphia: Temple University Press.

Veloso, Caetano. 2001. 'Carmen Mirandadada'. In Charles A Perrone and Christopher Dunn (eds), Brazilian popular music and globalization. Gainesville: Florida. 
Vianna, Harmano. 1999. The mystery of samba: popular music and national identity in Brazil. Chapel Hill: University of North Carolina Press.

Weinrobe, Phil and Naeem Inayatullah. 2005. 'A medium of others: rhythmic soundscapes as critical utopias'. In M I Franklin (ed), Resounding international relations: on music, culture and politics. New York: Palgrave.

Wilson, Olly. 1974. The significance of the relationship between Afro-American music and West African music. The Black Perspective in Music 2 (1): 3 -22.

. 1983. Black music as an art form. Black Music Research Journal 3: 1-22.

Zarakol,Ayse. 2011. After defeat: how the east learned to live with the west. New York: Cambridge.

\section{Acknowledgements}

A community effort made this essay possible. I am grateful to two anonymous referees. In addition, I received critical comments, encouragement, and appropriate filtering from the following friends and colleagues: Fernanda Alves, Asma Barlas, David Blaney, Matt Bozzone, Timothy Brennan, Emília Barreto Carvalho, Paulinho Chamon, Joel Dinerstein, Zillah Eisenstein, Natalia Felix, Xavier Guillhaume, Perin Gurel, Andy Lorentz, Megan MacKenzie, Himadeep Muppidi, Nick Onuf, Shaun Poust, Manu Samnotra, Robbie Shilliam, and Srdjan Vucetic. I received long, detailed, and nearly overwhelming responses from Daniel Levine, Quynh Pham, Steve Pond, Sara-Maria Sorentino, and Túlio Resende Baêta Zille. I wish to single out Steve Pond's pedagogy; his magnanimity, patience, and precision allowed me the belief that I could understand and write about this music. I dedicate this essay to the dazzling and nourishing students of my class at the International Relations Institute, Pontifical Catholic University of Rio de Janeiro, May-June 2010. Their remarkable energy launched this project.

\section{About the Author}

Naeem Inayatullah is professor of politics at Ithaca College. His work locates the Third World in the global political economy. With David Blaney, he is the co-author of Savage Economics (2010) and International Relations and the Problem of Difference (2004). He is editor of Autobiographical International Relations (2011), and co-editor of Interrogating Imperialism (2006) and The Global Economy as Political Space (1994). Recent works include "A Problem with Levels: How to Engage a Diverse IPE," (with David Blaney) in Contexto Internacional; "Global Capitalism, Inequality and Poverty" (with David Blaney), in Erskine and Booth, International Relations Theory Today (2016); and, Narrative Global Politics(2016) co-edited with Elizabeth Dauphinee. He serves as an associate editor for the Journal of Narrative Politics.

Received on 25 January 2015, and approved for publication on 21 June 2015.

\section{(cc) BY-NC} https://creativecommons.org/licenses/by-nc/4.0/ 
